\title{
Determination of the change which the internal friction of air experiences at different temperatures and under various pressures
}

\section{P. De Heen}

To cite this article: P. De Heen (1889) Determination of the change which the internal friction of air experiences at different temperatures and under various pressures, Philosophical Magazine Series 5, 28:172, 220-220, DOI: 10.1080/14786448908619861

To link to this article: http://dx.doi.org/10.1080/14786448908619861

曲 Published online: 08 May 2009.

Submit your article to this journal $[\pi$

Џll Article views: 2

Q View related articles $\longleftarrow$ 
and interesting matters. The book is accompanied by a fair index and a very necessary glossary of terms and symbols; for our author has a fad, and some of his work reminds us of the Appendix to Dodgson's ' Euclid and his Modern Rivals,' in which those who know, know that there are many things hard to be understood.

XXXI. Intelligence and Miscellaneous Articles.

ON LEIDENFROST'S PHENOMENON. BY K. S. KRISTENSEN.

THE author proves that the heat conveyed from the heated dish to the drop is not sufficient to explain the Leidenfrost phenomenon, but that the heat transmitted by conduction of the vapour must also be taken into account. Taking the temperature of the dish at $200^{\circ}$, that of the drop at $100^{\circ}$, and assuming that each are perfectly black, and that the conductivity of aqueous vapour is equal to that of air, the quantities of heat transferred by conduction and radiation are equal, if the distance between the dish and the drop is 0.135 centim. As the assumptions for the radiation are too favourable, the quantity of heat transmitted by conduction certainly preponderates.-Tidsskrift for Physik og Chemie [2] ix.'p. 161; Beiblätter der Physik, xiii. p. 155.

\section{DETERMINATION OF THE CHANGE WHICH THE INTERNAL FRICTION OF AIR EXPERIGNCES AT DIFFEREN'T TEMPERATURES AND UNDER VARIOUS PRESSURES. BY P. DE HEEN.}

$A$ brass tube $2 \mathrm{~cm}$. wide and $85 \mathrm{~cm}$. long, closed at both ends, carefully polished on the inside, is placed in an oil-bath, and a light brass cylinder $8.5 \mathrm{~cm}$. in length is allowed to fall through. The diameter of the cylinder is about $0.35 \mathrm{~mm}$. smaller than the clear width of the tube, so that the air on the fall of the cylinder must pass through an annular capillary slit. To the cylinder is attached an iron wire, so that it could be held up by an electromagnet; it was allowed to fall, and the time measured which elapsed before it struck against the bottom of the tube. Neglecting any possible friction of the cylinder against the sides of the tube, we have

$$
\eta=\mathrm{T} \text {. const., }
$$

where $\eta$ is the coefficient of internal friction of air. The temperature was varied from $0^{\circ}$ to $300^{\circ}$, the pressure of the air enclosed in the brass tube varied from 1 to $2280 \mathrm{~cm}$. of mercury. In agreement with earlier observers with the exception of M. Hirn, the author finds that at the pressure of the atmosphere the internal friction of the air increases as the two thirds power of the absolute temperature.

The variation of friction with the temperature appeared to have a maximum at $300 \mathrm{~mm}$. pressure. The dependence of the internal friction on the temperature between 10 and $78 \mathrm{~mm}$. pressure, as follows from the author's experiments, may be very well expressed by the ratio required by Clausius' theory ; that is, proportional to the root of the absolute temperature, which above $80 \mathrm{~mm}$. pressure is no longer the case.-Bull. Acc. Belg. [3] xvi. p. 195; Beiblätter der Physik, xiii. p. 124. 